\section{Study on Professors' Perception With Respect to Higher Education Institutions' Socially Responsible Initiatives}

\author{
Adriano Stadler ${ }^{\dagger}$ \\ Instituto Federal de Educação, Ciência e Tecnologia do Paraná \\ Edson Andrade dos Reis $\Omega$ \\ Faculdade Anhanguera de Joinville \\ Elaine Cristina Arantes $¥$ \\ Instituto Federal de Educação, Ciência e Tecnologia do Paraná \\ Jansen Maia Del Corso * \\ Pontifícia Universidade Católica do Paraná
}

\section{ABSTRACT}

The organization's socially responsible actions integration and stakeholders' demands is an increasingly encouraged practice by the market (Calabrese, Costa \& Rosati, 2016). This article looks at the perception that the professor holds on the Higher Education Institution's (HEI) socially responsible initiatives. Thus, a descriptive quantitative approach with non-probabilistic sample, accessibility and convenience was developed. The literature outlined the corporate social responsibility's (CSR) main concepts, theories applications and stakeholders. Empirical research collected data from the HEI's professors, through closed questionnaires. Descriptive analysis and multivariate statistics (cluster and factorial analysis) provided empirical evidence to the research. Results show the high concordance of professors in relation to the analysis categories: Economic, Legal, Ethical and Philanthropic, all of which are considered in this study, according to Carroll (2011). The sharpest legal dimension is given to the professors' perception. Philanthropic responsibility showed the lowest agreement, coming out to the Carroll (2011) studies, which have supported this work.

Keywords: Social responsibility, Corporate social responsibility, Stakeholder theory.

\section{INTRODUCTION}

In the first decades of the twenty-first century, companies have been requested by the society to strengthen the organizations' framework to promote social welfare and to raise awareness on the conservation of environmental resources for future generations. Its processes with regard to the production of goods or services provision must be reviewed considering its positive and negative influences on the population and the environment. The stakeholders' involvement with which the organization relates to, is fundamental in this process (Calabrese et al., 2016). Either internal or external agents (Freeman, 1984), either primary or secondary (Athkinson and Waterhouse, 1997) stakeholders (Ansoff and McDonnell, 1993) as the audience with which companies relate to, are best known and influenced by the managers decisions. According to the European Commission's recommendation (EC, 2011) companies must improve the internal processes implementation that integrate social, environmental, ethical and human rights to its business strategy and operations.
Corresponding author:

${ }^{\dagger}$ Instituto Federal de Educação, Ciência

e Tecnologia do Paraná.

E-mail: adriano.stadler@ifpr.edu.br

$\Omega$ Faculdade Anhanguera de Joinville.

E-mail: edson.reis@anhanguera.com

${ }^{¥}$ Instituto Federal de Educação, Ciência

e Tecnologia do Paraná.

E-mail: elaine.arantes@ifpr.edu.br

* Pontifícia Universidade Católica do

Paraná.

E-mail: del.corso@pucpr.br

Received: 07/01/2016.

Revised: 09/02/2016.

Accepted: 09/19/2016.

Published Online: 07/01/2017.

DOI: http://dx.doi.org/10.15728/bbr.2017.14.6.3 
Actions voluntarily practiced by companies to integrate economic objectives to social and environmental conflicts arising from business operations as well as the stakeholders' concern that make up the Christensen, Peirce, Hartman, Hoffman and Carrier (2007) are called the Corporate Social Responsibility (CSR). Not only them, but also other authors whose contributions to the topic will be presented subsequently in this work, deepened the approach of CSR in order to provide subsidies for companies to be perceived by stakeholders as being socially responsible. The image of a socially responsible company has been positively perceived by consumers that have rewarded their preference (Brunk and Blümelhuber, 2011). The value addition, which brings investment in socially responsible actions, is checked, according to Benabou and Tirole (2010), not only for the company, but also for its stakeholders. CSR has been a practice in this business only in recent decades (Calabrese et al., 2016).

These considerations motivated the present study by integrating CSR to a company's stakeholders' management. The study of the following theoretical assumptions are: 1 . Companies' shares to integrate economic, social and environmental dimensions are studied, a group called CSR is made up and contribute to the image of a company; 2. Stakeholders affected the public directly by the actions of companies and among them there are employees who are the organizations' partners in providing services and in the production of goods that are offered to the market; 3 . The company's CSR has an impact on its image and this is not only reflected in the consumer decision-making, but also in the perception that employees have on the organization for which they work for; 4. It is important that employees know and understand the organization's actions, which work in dimensions such as economic, legal, social and environmental, as it impacts their perception on the organization they work for.

The development of this study in the Brazilian educational context was decided by considering that there was a significant increase in the number of students that have been enrolled in higher education in Brazil during the last few years. According to the 20032013 Census of Higher Education released by the Brazilian Ministry of Education (Brazil, 2013), an increase of $76.4 \%$ in the total number of students entering higher education in Brazil. The number of private educational institutions reached 2009, accounting for $73.5 \%$ of university education institutes in 2013.

In the educational context, it is observed that in the United States since the 1990s, the university education institutions, both public and private, had already realized the importance of being able to respond to the needs of their target audience (Kotler and Fox, 1994). Contemporaneously, Othman and Othman (2014) found that private universities employ different strategies of public by using social responsibility, not only to preserve its legitimacy, but also in response to the demands of constant society's changes and pressures. In this context, CSR is regarded as an instrument for strengthening the educational institute reputation. Thus, CSR is within the strategic context of the university education institutes in relation to their stakeholders such as employees, students, suppliers, community, government and regulators, among others. Once defined, the premises and the context broke the following research problem: How the professors of a private institution in the state of Santa Catarina - Brazil perceive its dimensions: Economic, Legal, ethical and philanthropic of their CSR actions and what the most representative organization in the image formation to be socially responsible is. To answer this question, the article aims to: examine the perception of the professors of a private institution located in the state of Santa Catarina - Brazil on the practices of the educational institution that researched the economic, legal, ethical and philanthropic CSR. Specifically, the article proposes to: 1. 
BBR

14,6

Raise awareness of this group of stakeholders on the four dimensions of CSR; 2. Assess which of these dimensions are perceived more positively in the organization of image formation; 3. Analyze the professors' perception on HEI's socially responsible actions by focusing on shaping the brand image.

The methodology used in this was the exploratory and descriptive case study, through a survey research with professors. The exploratory study is composed of a secondary data collection that integrates the theoretical basis for the analysis. Empirical research promoted the survey of primary data in a given sample, whose analysis was based on descriptive and multivariate statistics such as cluster and factor analysis. We opted to research the professors, as it is a key stakeholders' category in the HEI teaching and learning process, as their respondent's proximity to the CSR actions. This proximity makes the teaching perception on CSR actions reflect to other stakeholders, such as students. By recognizing the professors' perception on CSR, the HEI can monitor the actions and promote effective communication strategies for their public.

\section{THEORETICAL FOUNDATIONS}

\subsection{CORPORATE SOCIAL RESPONSIBILITY'S HISTORICAL PERSPECTIVE}

Although CSR is a more widespread term from the 1990s, it was in 1953 that its concept was first treated, by being launched in the United States, the book "Social responsibilities of the business man" written by Howard Bowen. Corporate social responsibility "refers to the obligations of businessmen to adopt guidelines, and take decisions by following lines of action that are consistent with the purposes and values of our society" (Bowen, 1957:14). According to Alves (2003), the definition of Bowen seems to have an ambiguous character, to relate to the obligations with the need to reconcile the moral values of American society at that time. McGuire (1963) has pointed to the importance of economic interests, but also suggested a broad definition to the social responsibility business: the idea that the corporation has not only economic and legal, but also responsibilities to society that go beyond obligations (Carroll, 1979, 1991; Schwartz and Carroll, 2008).

Guided by this premise, there is the so-called economic line, led by authors like Milton Friedman, which have classic vision of social responsibility. For this author, the social responsibility of a company should be focused on generating more profits, otherwise, their managers and executives will be using the shareholder's money in a way that does not interest the latter (Friedman, 1970). It also highlights that the company cannot use the money that consumers have given it in exchange for goods or services to social or environmental actions, which may not agree. Moreover, they would be paying more to support these actions and shareholders, in turn, they would be receiving a return which is lower than they are entitled to (Friedman, 1972). From the advent of the CSR concept several academic studies on the subject emerged, highlighting authors like Levitt (1958), Davies (1960), Friedmann (1970; 1972), Carroll (1979, 1991), Jones (1980) Melo Neto and Froes (1999), Ashley Coutinho and Tomei (2000); Hartley (2005). In Brazil, the term became known in 1998 when the Institute Ethos was created. That was a civil society initiative, as a non-profit organization aimed to promote, among Brazilian companies, some practices such as ethical management and accountability (Instituto Ethos, 2016).

Archie Carroll, one of the most active researchers on the subject, was one of those responsible for popularizing the concept of CSR, in the academic and industry fields. Carroll is referenced by most of the scientific studies published in national and international journals that are dealing with CSR in the form of dimensions. Economic, Legal, Ethical 
and Philanthropic responsibility are brought as part of a construction which is capable of synthesizing the main actions and impacts of the company with its stakeholders (Carroll, $1979 ; 1991)$ and more recently by the expansion of the construct, called VBA model (Carroll and Schwartz, 2008). "The value, balance and responsibility transparency, they called VBA Model. VBA is an English acronym that refers to the terms value, balance and accountability" (Lyra and Souza, 2013:4). The VBA model, according to Schwartz and Carroll (2007) comprises three variables: value, balance and accountability.

CSR goes beyond performing specific actions with specific audience or social actions focused on certain groups for a period. The socially responsible management focus should be on compliance with the laws and regulations that are enacted by governments in their federal, state and municipal levels, as well as by activities regulators. According to Stadler and Souza (2008), the ethical responsibility involves rules, standards, norms and expectations that reflect the concern that stakeholders have regarding the maintenance of protection and respect to all the ones involved with the organization. Finally, the philanthropic responsibility deals with social projects aimed at promoting and maintaining the welfare, life quality and community nature of actions that contribute greatly to the organization's positive image formation in the community. Other authors corroborate the dimensions of CSR defined by Carroll $(1979 ; 1991)$ such as shown in Table 1.

Table 1. CSR dimensions and concepts

\begin{tabular}{ll}
\hline CSR dimensions & Definition \\
\hline Economical & The company must be profitable. It is the basis on which to support the other liabilities of the company \\
(Carroll, 1991). By disregarding social issues operating costs increase as well as affecting sales, causing a \\
negative impact on the brand image and loss of talent (Grayson and Hodges, 2002). The CSR strategic \\
management is relevant to the achievement of competitive advantage (Tachizawa, 2004).
\end{tabular}

The evolution of discussions with respect to socially responsible awareness resulted in the ISO 26000 issue (Associação Brasileira de Normas Técnicas [ABNT], 2010). It is a standard that defines the directions for the companies' performance towards sustainability based on seven dimensions. These dimensions are Organizational governance; Human rights; Labor practices; Environment; Fair and legal practices for operation; Customer relations; Involvement and community development.

As a result, the creation of regulations such as ISO 26000 is management tools in pursuit of social and economic gains. Lee and Carroll (2011) point out that the companies that seek to be profitable should respect the laws as well as to follow ethical behavior and return to society through philanthropy. Among these responsibilities, there are challenging issues that influence companies' operations globally.

\subsection{VBA MODEL: VALUE, BALANCE AND ACCOUNTABILITY}

From the breadth of the concept of corporate social responsibility, the authors Schwartz and Carroll (2007) re-dimensioned the CSR concept, which now comprises other areas considered as integral and complementary to the social responsibility concept. The 
BBR

14,6

confluence of different topics related to the field of business and society are related, covering CSR, Business ethics, Theory of stakeholders, Sustainability and Corporate Citizenship. Such joint aimed to provide a language among the business field scholars and society, and from the study of its definitions and applications in empirical field resulted in three constructs, which came to understand. By bringing together three concepts: value, balance and accountability, as presented in Table 2, a normative proposition in an attempt to incorporate and join conceptually issues not previously connected emerges in this way.

Table 2. VBA Model for social responsibility

\begin{tabular}{ll}
\hline $\begin{array}{l}\text { VBA Model } \\
\text { dimensions }\end{array}$ & Description \\
\hline Value & $\begin{array}{l}\text { Fundamental element of any business and society field. Value is created by taking into account the needs of society } \\
\text { through the production of goods and services, in order to exceed its expectations without causing damage from its } \\
\text { production process. }\end{array}$ \\
\hline Balance & $\begin{array}{l}\text { Involving the stakeholders interests (groups with which the company relates to) and non-stakeholders (natural } \\
\text { environment), which are satisfied in a balanced way so that everyone gets benefits from the organization's actions. }\end{array}$ \\
\hline Accountability & $\begin{array}{l}\text { Acting responsibly means that companies and their agents try to meet their economic, legal, philanthropic } \\
\text { and ethical responsibilities, while printing a larger view of the business functions for the benefit of society. It is } \\
\text { supported by the normative principles of accountability, transparency, keeping promises, liability, honesty, loyalty } \\
\text { and integrity. }\end{array}$
\end{tabular}

Such elements are from the field of business and society, which are CSR, business ethics, stakeholder theory, sustainability and corporate citizenship. From these constructs, a broader and modern proposal for Social Responsibility (SR) in organizations converged. This model follows the evolution of studies that will be fitting with the social changes and pressures from stakeholders. Shareholders, customers, employees, suppliers, community activists and social groups take part of the group of stakeholders (Freeman, 1984).

\subsection{STAKEHOLDER THEORY}

Historically the term is not new. Barnard (1938) presented the first evidence of the stakeholders' concept. The Stanford Research Institute defined in 1960 that managers must understand and take into account the different stakeholders concerns, in order to obtain their commitment. Yet in order to define the concept, Ansoff and McDonnell (1993) treat stakeholders as affected interest groups directly by the company's behavior. However, from Freeman (1984) derived hundreds of scientific researches and publications that address the concept and the author which is often cited in research and theoretical references on the subject. Thereupon, Stoner and Freeman (1985) state that there are two types of stakeholders: internal and external, and Athkinson and Waterhouse (1997) propose that the stakeholders are classified into primary and secondary. In both classifications, it can be seen that either primary or internal, are those directly linked to the operations and business decisions, and have greater control; and external or secondary, are those belonging to the external environment to the organization, and additionally affect and are affected by it; nevertheless with less capacity to control and manipulation.

Even after more than three decades subsequent to the Freeman's publication (1985) reference work, there is much disagreement regarding what type of entity may be considered as stakeholders and how their management processes are. Sautter and Leisen (1999) define the stakeholder's management process in three steps: identify its stakeholders and their respective interests; know the process required to manage organizational relationships between them; and manage transactions and bargaining between organizations and stakeholders. Yet, Sender and Fleck (2004) assert that the process of managing stakeholders comprises actively listening, process and constructively answer the wishes, values and 
beliefs of all parties that nurture an interest in the organization. Ranängen (2013) emphasizes that stakeholder engagement is a key move for companies that are able to follow established standards such as ISO 26000. However, it is necessary to emphasize that this process may differ in interests, priorities, values and missions cause disagreements among stakeholders (Arenas; Lozano \& Albareda, 2009).

Churchill and Peter (2000) extend the previous approaches bringing the idea that stakeholders are groups or individuals who are also interested in the consequences of the organizations' decisions, and are able to influence them with the same intensity. Tenorio (2004) brings up the idea of CSR in organizational systems view, so that organizations interact with various agents, interfering and receiving environmental influences. Benabou and Tirole (2010) emphasize that investments in social responsibility create value for its stakeholders. Decisions taken at all levels of the enterprise should consider the perception of its set of stakeholders. The transparency of this movement is through a systematic flow of internal communication within the company and external to society (Asif, Searcy, Garvare, $\&$ Ahmad, 2011). Table 3 summarizes examples of bond that appears between stakeholders and the investment made by organizations in social responsibility, from a number of authors on the subject.

Table 3. Established link between stakeholders CSR investment

\begin{tabular}{|c|c|c|}
\hline Stakeholders & Links stablished with CSR & Authors \\
\hline $\begin{array}{l}\text { Board } \\
\text { directors }\end{array}$ & $\begin{array}{l}\text { CSR as corporate strategy as a way to create value and to } \\
\text { generate competitive advantage. }\end{array}$ & Porter and Kramer (2002); Cespa and Cestone (2007) \\
\hline Shareholders & $\begin{array}{l}\text { Link between investment in CSR and investors' } \\
\text { reputation. }\end{array}$ & Barnea and Rubin (2010) \\
\hline \multirow{2}{*}{ Governance } & $\begin{array}{l}\text { CSR is linked to corporate governance especially with } \\
\text { regard to the transparency of strategic decisions of senior } \\
\text { management. }\end{array}$ & Beltratti (2005); Clarke (2005); Harjoto and Jo (2011) \\
\hline & $\begin{array}{l}\text { Development of conduct codes and corporate policies on } \\
\text { human rights, standards for human resources and climate } \\
\text { change. }\end{array}$ & Rasche and Kell (2010) \\
\hline \multirow[t]{2}{*}{ Consumers } & $\begin{array}{l}\text { Growth of the link between consumer perception and } \\
\text { organizations' socio-environmental actions has increased } \\
\text { in recent decades. }\end{array}$ & Brunk and Blümelhuber (2011) \\
\hline & $\begin{array}{l}\text { Not all consumers are also concerned about the social and } \\
\text { environmental organizations' performance. }\end{array}$ & Lämsä et al (2008) \\
\hline
\end{tabular}

Effective stakeholder management and the organization's socially responsible actions, nurture benefits in various spheres. Cheng, Ioannou and Serafeim, (2014) point out those companies with best performance in CSR that are faced with fewer restrictions regarding capital. This happens due to different reasons, one of them is related to a strong correlation between higher performance in CSR and stakeholder engagement as opportunistic behavior is reduced (Benabou and Tirole, 2010; Eccles, Ioannou \& Serafeim, 2012). In addition, companies that invest in CSR may differentiate themselves while ensuring their survival in the market (Spence, 1973; Benabou and Tirole, 2010; Dhaliwal et al., 2011).

After the presentation of Social Responsibility theory and Stakeholders theory, it is relevant to know a few studies on SR initiatives in the HEI context. The relation between CSR concepts and HEI is a subject that has been developed in several studies in different countries. The education in contents related to stakeholders such as employees, consumers and environment is the approach adopted by Vázquez, Lanero and Licandro (2013:145) in their study, which reveals that in Uruguay, there is are a "generalized awareness of the relevance of socially responsible criteria, in line with a high demand of CSR education". Slavova and Bankova (2015:57) consider practices of CSR education adopted in Bulgaria 
BBR

14,6

598

to discuss how universities may help Bulgarian companies to develop socially responsible initiatives. In this study, results indicate that there is a "gap between the demand and supply of CSR education for business and management graduates in Bulgarian universities (Bachelor and Master programs)". In the Middle East, Alzyoud and Bani-Hani (2015) present the case of the Hashemite University to discuss how the concept of University Social Responsibility (USR) may help universities to be competitive as well as to achieve sustainability and development. In Brazil, Sánchez-Hernandez and Mainardes (2016) have developed a study whose results confirm the direct and positive relation between the students' satisfaction and the HEI that integrate CSR to their strategy, management activities and programs. Mishra and Awasthi (2016:56) consider Institutional Social Responsibility (ISR) in the context of HEI in India as "awareness towards aspects of ISR has been increasing, especially in Indian Universities". On one hand, their study indicates lack of awareness towards the concept of ISR, however on the other hand, it indicates that HEI have a significant acceptance of ISR initiatives. They suggest including ISR initiatives in the strategic decisions of HEI to help society as well as to gain competitive advantage.

\section{METHODOLOGICAL PROCEDURES}

This quantitative study used the case study method (Yin, 2001). The case is an integrated and limited system, focused on an isolated phenomenon or entity (case), this approach seeks to describe the phenomenon deeply (Merriam, 1998). The case study is chosen when the researcher wants to find out "how" and why "and when there is little control over the contemporary phenomena (Yin, 2001).

For this research, first, a bibliographic review was conducted and guided by classical and contemporary authors, presenting the theory and recent empirical CSR studies. In sequence, it was developed an empirical research involving its design in the following dimensions: research quality, sample composition, data collection and finally, data analysis method, with descriptive and multivariate statistics analysis, as cluster and factor analysis, in order to provide empirical evidence for the research. The research is characterized as a descriptive study, with a quantitative approach, making use of a non-probability sampling accessibility and professors' convenience of a university educational institution in the Brazilian Northern State of Santa Catarina. Regarding the sample, it is an intentional one. In order to quantify the number of cases, the literature suggests that the sample should have more than 50 observations. It is deemed advisable at least 100 cases to ensure more robust results, so that they have scientific validity. The ratio between the number of cases and the number of variables must exceed the ratio of five to one (Hair Jr., Anderson, Tatham, and Black, 2006; Martins, Fischer, Oliveira, Teixeira, Costa, Marinho, Perestelo, Latorre and Costa, 2002; Arango, 2005).

The data collection instrument was adapted from Stadler (2007) and Stadler and Souza (2008) studies, so that the categories and sub categories of analysis are based on Carroll's studies $(1979,1991)$ : economic, legal, ethical and discretionary or philanthropic responsibility. The questionnaire used the numeral scale with adjectival poles, 6 points, considering that this method collects a number of items that indicate negative and positive attitudes about an object (Mattar, 2014). This type is also known as semantic differential scale, according to Oliveira (2001) his virtue that it is able to grasp the meanings of objects that have subtle and difficult distinctions to be discovered otherwise. The scale in question has answer choices from 1 (no agreement) to 6 (maximum agreement), as shown in Figure 1. 
The HEI researched is characterized by offer in the State of Santa Catarina 17-person graduate courses, with approximately 4,000 students, the latter being the shift with the highest percentage of students. The Institution is a private institution with over 10 years of accreditation with the Ministry of Education (MEC). The subjects are the professors of the 14 undergraduate courses at IES researched. The questionnaire and the data collection occurred from February to April 2015. The questionnaires were sent to the professors by email. One hundred and forty six professors were contacted. There was a return of 103 completed questionnaires, giving a percentage of $71 \%$ of respondents' answers. The method of statistical analysis data is presented along with the field research results in the following items.

\section{ANALYSIS OF RESULTS}

The analysis is structured according to the research objectives and measured variables. The method of data analysis was through the extraction of univariate and multivariate statistics for the summarization and classification of data according to criteria that facilitated and allowed the interpretation of the results, according to the proposed objectives, with the help of two softwares: Statistica and SPSS. The univariate data analysis procedures are part of the first step. Descriptive statistics were used on the processing of data, targeting description frequency, mean and standard deviation of the variables (Verdinelli, Souza \& Ferraz, 2007).

\subsection{PROFESSORS' PERCEPTION THROUGH DESCRIPTIVE STATISTICS}

First, it was performed the stratification of descriptive statistics of the four dimensions studied. In the assessment of responsibilities, it was found that the economical responsibility (Table 4) had concentrated high concordance answers. Noteworthy is the "perception concern about unfilled vacancies in undergraduate courses", highlighting its direct impact on the economic responsibility of the institution.

Table 4. Descriptive statistics - Economical responsibility

\begin{tabular}{|c|c|c|c|c|c|}
\hline A Variables Economical Responsibility & $\mathrm{N}$ & Média & Valor mínimo & Valor máximo & Desvio padrão \\
\hline $\begin{array}{l}\text { A1 - The educational institution offers courses that meet the } \\
\text { demand for university education. }\end{array}$ & 103 & 4.96 & 4.00 & 6.00 & 0.64 \\
\hline A2 - The monthly fee is fair. & 103 & 4.88 & 2.00 & 6.00 & 0.98 \\
\hline $\begin{array}{l}\text { A3 - The opening of new courses at HEI contributes to job } \\
\text { creation. }\end{array}$ & 103 & 5.58 & 2.00 & 6.00 & 0.73 \\
\hline $\begin{array}{l}\text { A4 - The closure of courses is detrimental to the staff of the } \\
\text { institution. }\end{array}$ & 103 & 5.58 & 2.00 & 6.00 & 0.81 \\
\hline $\begin{array}{l}\text { A5 - The existence of unfilled vacancies is harmful to the } \\
\text { institution. }\end{array}$ & 103 & 5.61 & 3.00 & 6.00 & 0.70 \\
\hline A6 - The investments in infrastructure is satisfactory. & 103 & 3.00 & 1.00 & 5.00 & 1.29 \\
\hline A7 - The investments in teacher training is satisfactory. & 103 & 3.34 & 1.00 & 6.00 & 1.34 \\
\hline A8 - The salary rewards are satisfactory. & 103 & 3.01 & 1.00 & 6.00 & 1.30 \\
\hline
\end{tabular}


BBR

14,6

600

They also emphasized the responses located in the average agreement and lower incidence to low agreement. The lower perception was due to the "investment in physical structure, and satisfactory salary rewards," thus concluding that the professors' perception that these elements are not correlated with the economic responsibility of the organization. Precisely these are the issues with high standard deviation, 1.29 and 1.30, respectively, highlighting the low knowledge of these items in relation to the economic aspects.

In terms of legal responsibilities (Table 5), the aspects that deserve greater emphasis are the "dismissal" and "workload reduction" as just treat the employment relationship that in his perception has greater damage to the faculty. The issue of "physical integrity" is the lowest perception, bringing out that professors may be unaware of the legal factors of the issue of safety. This item also has the greatest standard deviation, i.e. is of lesser homogeneity of the construct.

With regard to the ethical responsibility (Table 6), the "access for minorities" was the greatest perception factor (average 5.16) and low standard deviation (0.79), far reference Stadler's study (2007) which found this item an average of 4.43 and standard deviation of 1.58 , leading to the conclusion that in the period between the two surveys ( 7 years) may have increased the perceived responsibility of HEI to provide schooling for minorities, promoting accessibility, and especially including those who were on the margins of society.

With regard to philanthropic responsibility (Table 7), the "social projects" in teacher perception also have the highest perception of the average (mean 5.43) and low standard deviation (0.80) demonstrating that the social actions and communication actions to this public are being effective. However the question of resources for investment in projects demonstrated heterogeneity in responses (standard deviation 1.27). Yet the question of "volunteering" is the item with the lowest perception (average 3.93), indicating a factor for the educational institutions with the need to develop integrated programs among its stakeholders, to develop social actions, especially by volunteering, this idea is confirmed by the high standard deviation index (1.16).

Table 5. Descriptive statistics - Legal Responsibility

\begin{tabular}{|c|c|c|c|c|c|}
\hline $\begin{array}{l}\text { B - Variables } \\
\text { Legal Responsibility }\end{array}$ & $\mathrm{N}$ & Average & $\begin{array}{l}\text { Minimum } \\
\text { value }\end{array}$ & $\begin{array}{l}\text { Maximum } \\
\text { value }\end{array}$ & $\begin{array}{l}\text { Standard } \\
\text { deviation }\end{array}$ \\
\hline B1 - The institution complies with all applicable laws & 103 & 4.95 & 3.00 & 6.00 & 0.80 \\
\hline $\begin{array}{l}\text { B2 - The institution complies with labor obligations under the } \\
\text { Consolidation of Labor Laws (CLT) }\end{array}$ & 103 & 5.11 & 3.00 & 6.00 & 0.79 \\
\hline B3 - The institution respects the Consumer Protection Code & 103 & 4.50 & 2.00 & 6.00 & 1.34 \\
\hline B4 - The institution respects the environmental legislation & 103 & 5.01 & 2.00 & 6.00 & 0.87 \\
\hline $\begin{array}{l}\text { B5 - The institution respects the health and safety legislation to } \\
\text { protect the physical integrity of its employees }\end{array}$ & 103 & 4.50 & 2.00 & 6.00 & 1.34 \\
\hline $\begin{array}{l}\text { B6 - The resignation and the workload reduction are harmful to } \\
\text { the employee }\end{array}$ & 103 & 5.67 & 4.00 & 6.00 & 0.64 \\
\hline
\end{tabular}

Table 6. Descriptive statistics - Ethical responsibilities

\begin{tabular}{|c|c|c|c|c|c|}
\hline C Variables - Ethical responsibilities & $\mathrm{N}$ & Average & $\begin{array}{l}\text { Minimum } \\
\text { value }\end{array}$ & $\begin{array}{l}\text { Maximum } \\
\text { value }\end{array}$ & $\begin{array}{l}\text { Standard } \\
\text { deviation }\end{array}$ \\
\hline C1 - I am aware of the existence of the institution's code of ethics & 103 & 3.90 & 1.00 & 6.00 & 2.24 \\
\hline C2 - The institution maintains an ethical work environment & 103 & 4.77 & 2.00 & 6.00 & 1.29 \\
\hline C3 - The institution respect the moral integrity of employees & 103 & 5.14 & 3.00 & 6.00 & 1.15 \\
\hline C4 - The institution provides access to minorities & 103 & 5.16 & 3.00 & 6.00 & 0.79 \\
\hline C5 - The institution does not harm anyone voluntarily & 103 & 5.01 & 2.00 & 6.00 & 1.40 \\
\hline C6 - The institution disapproves of discrimination and respect differences & 103 & 5.11 & 2.00 & 6.00 & 1.37 \\
\hline C7 - The institution combat sexual harassment and morale among staff and students & 103 & 5.01 & 1.00 & 6.00 & 1.43 \\
\hline C8 - The institution disapproves of unfair dismissal policies & 103 & 4.62 & 1.00 & 6.00 & 1.62 \\
\hline
\end{tabular}


Table 7. Descriptive statistics - Philanthropical responsibilities

\begin{tabular}{|c|c|c|c|c|c|}
\hline D - Variables - Philantropical responsibilities & $\mathrm{N}$ & Average & $\begin{array}{l}\text { Minimum } \\
\text { value }\end{array}$ & $\begin{array}{l}\text { Maximum } \\
\text { value }\end{array}$ & $\begin{array}{l}\text { Standard } \\
\text { deviation }\end{array}$ \\
\hline D1 - I am aware of social projects developed by the institution & 103 & 5.43 & 3.00 & 6.00 & 0.80 \\
\hline $\begin{array}{l}\text { D2 - The institution invests material, human and financial resources in } \\
\text { social projects }\end{array}$ & 103 & 4.67 & 3.00 & 6.00 & 1.27 \\
\hline $\begin{array}{l}\text { D3 - The institution encourages the participation of students in volunteer } \\
\text { activities }\end{array}$ & 103 & 4.87 & 3.00 & 6.00 & 1.16 \\
\hline $\begin{array}{l}\text { D4 - The institution encourages the participation of faculty and staff in } \\
\text { voluntary activities }\end{array}$ & 103 & 3.93 & 1.00 & 6.00 & 1.75 \\
\hline $\begin{array}{l}\text { D5 - The institution promotes the welfare of all involved stakeholders } \\
\text { (students, teaching staff, etc.) }\end{array}$ & 103 & 4.09 & 1.00 & 6.00 & 1.75 \\
\hline $\begin{array}{l}\text { D6 - The institution promotes the quality of life of its employees, students } \\
\text { and others involved }\end{array}$ & 103 & 4.02 & 1.00 & 6.00 & 1.72 \\
\hline
\end{tabular}

Table 8. Average results for each dimension of responsibility

\begin{tabular}{lc}
\hline RESPONSIBILITIES & AVERAGE RESULTS \\
\hline A - Economic & 4.49 \\
B - Legal & 4.96 \\
C - Ethics & 4.84 \\
D - Philantropic & 4.50 \\
\hline
\end{tabular}

Table 8 summarizes the categories examined in terms of perception of socially responsible actions taken by HEI researches. You can have an overview of the values obtained by applying the data collection instrument with the professors. The most significant result, with the highest average of the four constructs was the legal responsibility of the HEI averaging 4.96. Analyzing the overall averages of 4 responsibilities through the range 0 to 6 points, it was found that the 4 surveyed constructs are located in high levels within the category average agreement (between 4.50 and 4.96).

Table 9 summarizes which were the categories of higher and lower impact identified by professors as their perception in relation to the categories of economic, legal, ethical and philanthropic responsibility. Among the sub categories of low impact, the research

Table 9. High and low impact sub categories

\begin{tabular}{|c|c|c|c|c|}
\hline $\begin{array}{l}\text { Categories of } \\
\text { analysis }\end{array}$ & \multicolumn{2}{|c|}{ High impact sub categories } & \multicolumn{2}{|c|}{ Low impact sub categories } \\
\hline $\begin{array}{l}\text { Economic } \\
\text { responsibility }\end{array}$ & unfilled vacancies & $\begin{array}{l}\text { direct impact on the economic } \\
\text { responsibility of the institution }\end{array}$ & Infrastructure & $\begin{array}{l}\text { These elements are not } \\
\text { related to the economic } \\
\text { responsibility of the } \\
\text { organization }\end{array}$ \\
\hline Legal responsibility & Dismissal and workload & $\begin{array}{l}\text { Employment relationship that in } \\
\text { his perception has greater }\end{array}$ & Health and safety & $\begin{array}{c}\text { Professors may be unaware } \\
\text { of the legal factors of the } \\
\text { issue of job security }\end{array}$ \\
\hline $\begin{array}{l}\text { Ethical } \\
\text { responsibility }\end{array}$ & $\begin{array}{l}\text { Access of minorities to } \\
\text { studies }\end{array}$ & $\begin{array}{l}\text { Since the study Stadler ( } 2007) \text {, } \\
\text { which found this item an average } \\
\text { of } 4.43 \text { and standard deviation of } \\
1.58 \text {, it may have increased the } \\
\text { perceived responsibility of the } \\
\text { institution to provide schooling } \\
\text { for minorities, promoting } \\
\text { accessibility and, especially, } \\
\text { including those who were on the } \\
\text { margins of society. }\end{array}$ & $\begin{array}{l}\text { Unfair dismissal } \\
\text { policies }\end{array}$ & $\begin{array}{l}\text { Professors do not seem to } \\
\text { realize that the institution } \\
\text { disapprove unfair dismissal } \\
\text { policies. }\end{array}$ \\
\hline $\begin{array}{l}\text { Philantropic } \\
\text { responsibility }\end{array}$ & Social projects & $\begin{array}{l}\text { The communication actions of } \\
\text { social actions are effective from } \\
\text { the point of view of professors }\end{array}$ & Volunteering & $\begin{array}{l}\text { It is necessary to develop } \\
\text { integrated programs } \\
\text { among the stakeholders of } \\
\text { the institution }\end{array}$ \\
\hline
\end{tabular}


BBR

14,6

602

indicates the need for investment in the institution disclosure of legal factors on safety. Moreover, the results obtained in the research to improve the professors' perception in relation to the philanthropic responsibility of the organization, it is important to invest in integrated volunteer programs.

By the results presented herein, it seems relevant that the organization provides transparency to their criticism for unfair dismissal policies in order to be perceived by professors for their ethical action in disconnections.

\subsection{PROFESSORS” PERCEPTION THROUGH MULTIVARIATE ANALYSIS}

In the second stage of data analysis, we used the multivariate statistics that initially develops clusters analysis, or clustering technique by using the agglomerative hierarchical method, in which the objects are grouped similarly to a taxonomic classification, and represented, in a chart with a tree structure, called dendrogram. The basic procedure is to compute a distance matrix or similarity between individuals, checking the similarity of the constructs in order to group them by the Euclidean distance method, or the grouping is made on the basis of similarity or dissimilar distances when units are grouped, proximity is usually indicated by a distance (Hair Jr. et al., 2006; Escobar, Lizote \& Verdinelli, 2012). The Euclidean distance provides a measure of the number of pairings and also a large number of non-pairings, which indicate less similarity. Its formula is shown in Figure 2.

$$
d_{(A, B)}=\left[\sum_{i=1}^{0}\left(X_{i(A)}-X_{i(B)}\right)^{2}\right]^{1 / 2}
$$

Figure 2. Calculation formula of the Euclidean distance

Source: Hair Jr. et al., 2006

\subsubsection{CLUSTERS ANALYSIS}

The main objective of the cluster analysis is to divide a set of variables into small groups based on similarity of these variables in relation to a specific set of characteristics making it a useful tool when making the analysis of a data set in many different situations (Pereira, 2001; Hair Jr. et al., 2006; Ferreira et al., 2012; Malhotra, 2001; Escobar et al., 2012). Figure 3 shows the grouping of all the variables, three clusters formation were identified and obtained by means of a cross-section taken at a greater distance between the clusters, which was obtained by the parameterization discretion of the researcher.

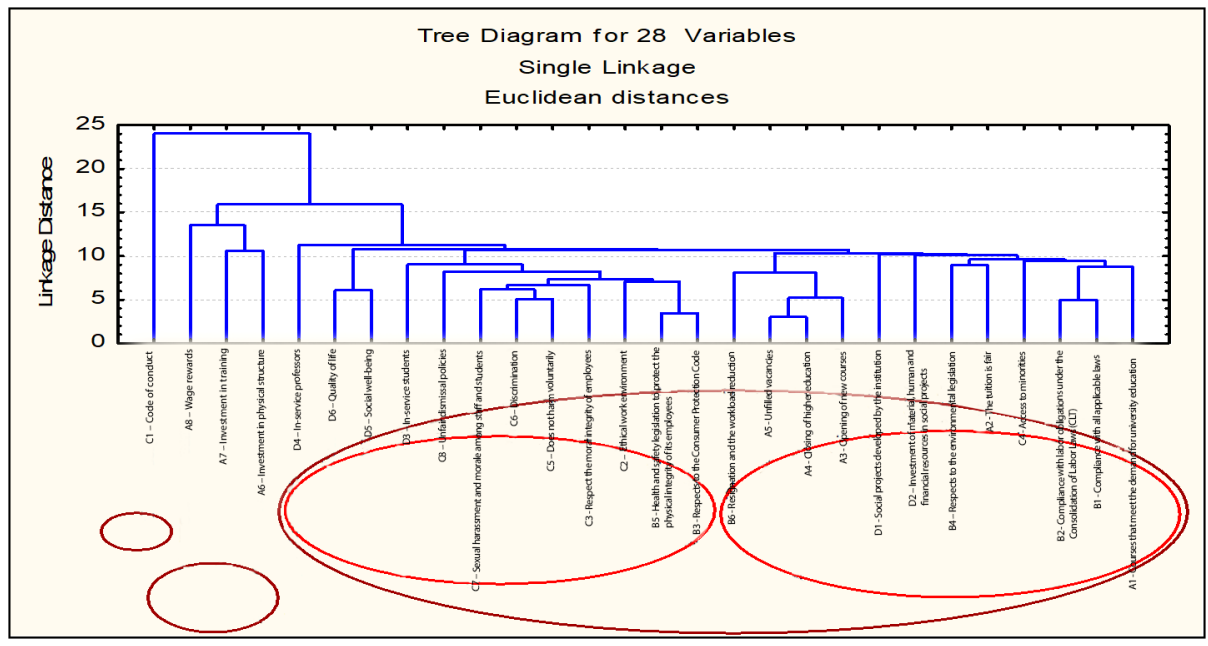

Figure 3. Dendogram of CSR variables 
The first cluster is formed by the variables belonging to the Ethical responsibilities through C1 item "code of conduct". The second cluster was formed within the elements of Economic Responsibilities for three variables, which are A8 "wage rewards are satisfactory," A7 "investment in teacher training is satisfactory," and A6 "investment in physical structure is satisfactory "which are linked to issues relating to investment of HEI in infrastructure and personnel. It identified a large grouping of variables forming the third cluster with 24 variables, in which there are items with very small Euclidean distances. These variables could be removed in order to redo the clusters analysis, and therefore decrease the number of items to be analyzed.

\subsubsection{FACTOR ANALYSIS (FA)}

After the cluster analysis, we developed an exploratory factor analysis to verify the onedimensionality of the constructs under study, with the purpose of describing the dependence structure of a set of variables, through the creation of factors, variables that theoretically measure commonalities. The treatment is made from the correlation matrix between the variables, which was made through the following steps: a) determining the eigenvalues and eigenvectors; b) rotate the factors; c) interpret the factors; d) calculate the factor scores and select the proxies; and finally, e) determining the model fit. It used the Kaiser criterion for the retention of factors. Regarding the pattern of correlation between the variables, the correlation matrix should display most of the coefficients with values above 0.30. Finally, verified the statistical Bartelett Test of Spherecity (BTS) is to be statistically significant ( $p$ $<0.05$ ) (Malhotra, 2001; Hair Jr. et al., 2006).

A factor analysis (FA) was conducted initially by measuring the adequacy of the variables involved to verify the possibility of implementing the analysis, through the KMO test provided the value 0.577 . By analyzing these figures, it is shown that FA can be performed by obtaining a reasonable degree of suitability to be above 0.5 as the classification of KMO, which measures the adequacy of the data. values equal to or smaller than 0.5 indicate that the realization of the factor analysis is unsatisfactory due to poor correlation between the variables After applying Bartlett's sphericity test, it was found that the significance of the variables involved, to give a statistically significant result $(\mathrm{p}<0.000)$.

In all the tests, the data were adequate to AF. Approximately $72 \%$ of the variability in the data is accounted for by four main factors. This means that 28 original variables, with 103 observations, we started to use four factors, which represent the original set. Thus, there was a reduction of dimensionality, as can be seen in Table 2. After the extraction of the eigenvalues and percentage of the variance, over $70 \%$ justified the use of four factors. For a better view of AF, the correlations of the four factors to be worked on FA arerepresented graphically, which originates in Figures 4, 5 and 6. Through the principal plan, it appears as shown in Figure 4, the behavior of the most representative variables, two cloud points, one on the $\mathrm{Y}$ axis, in which are A3 variables "The opening of new courses in the HEI contributes for job creation and job creation fronts ", with an average 5.58; A4, "The closing of higher education is detrimental to employees of HEI", with an average of 5.58 in the answers; and A5, "the existence of unfilled vacancies is detrimental to the HEI" with an average of 5.61 in the answers. In the X-axis there is a cloud C block variables, and C6 stand out, "HEI disapproves discrimination and regards the differences", mean 5.11, and C4 "HEI provides access to minorities" averaging 5.16.

In Figure 5 it was featured on the X axis C5 variable, "HEI harms no one voluntarily", averaging 5.01, and the axis Y, B1, "The HEI complies with all applicable laws," and B2 "the HEI meets labor obligations under the Consolidation of work Laws (CLT)", with average 4.95 and 5.11, respectively. 
BBR

14,6

604

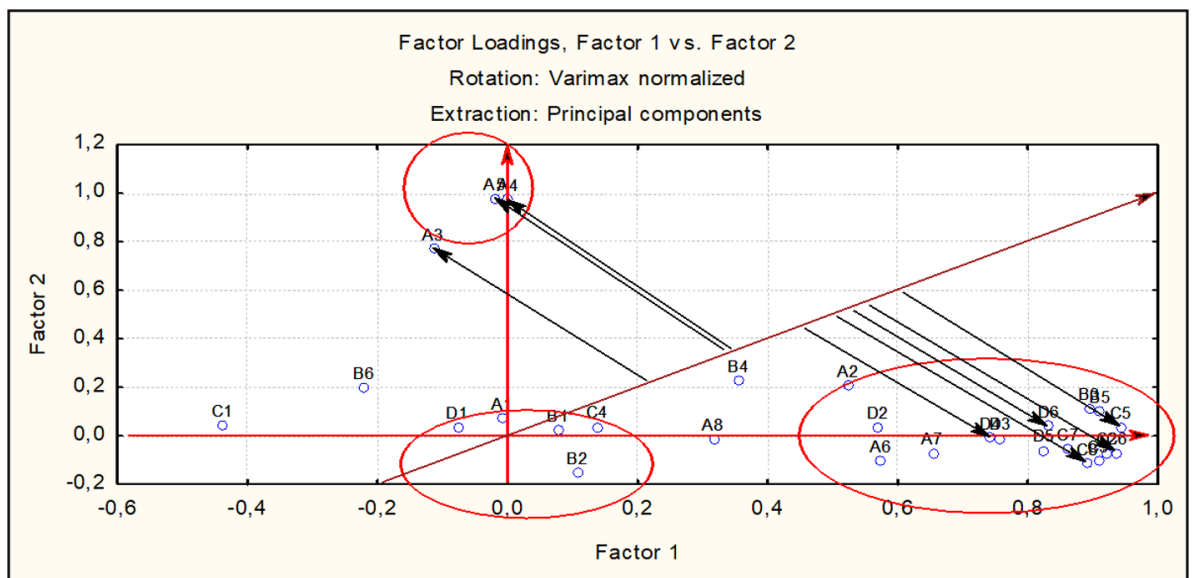

Figure 4. Representation of Factor 1 versus Factor 2

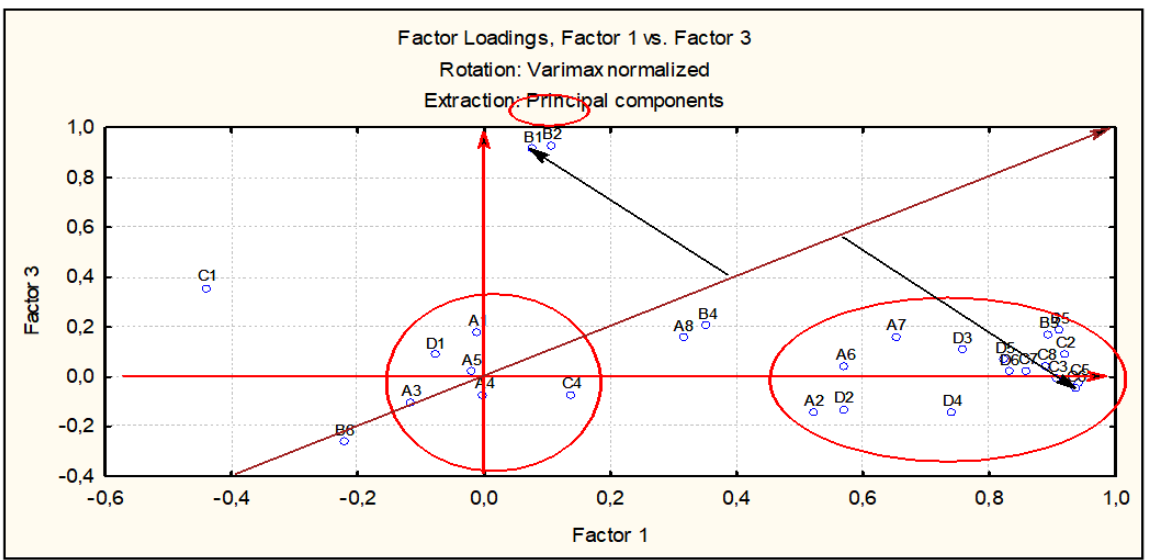

Figure 5. Representation of Factor 1 versus Factor 3

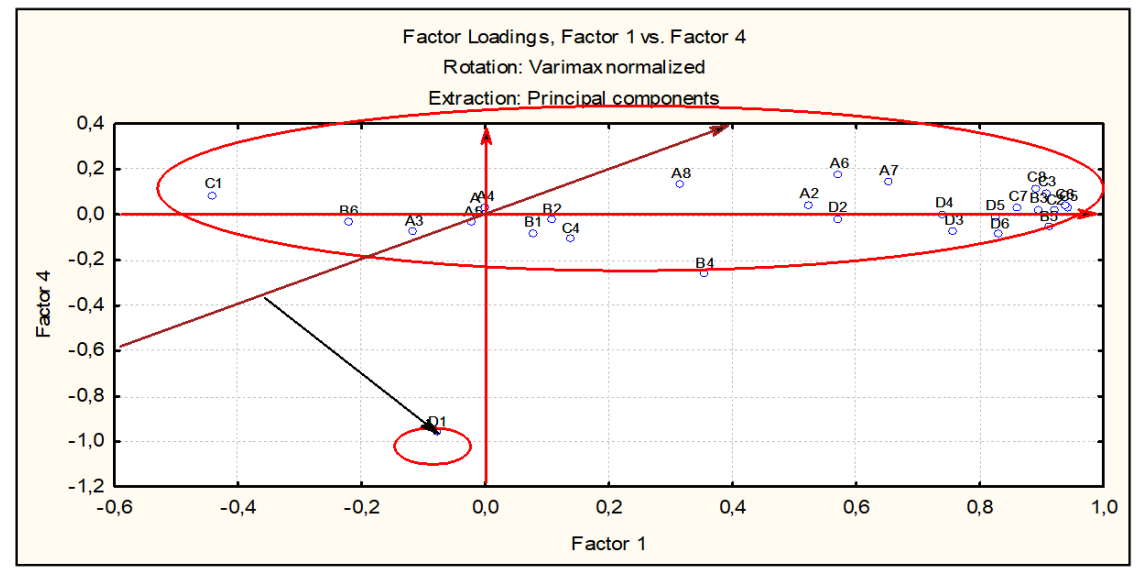

Figure 6. Representation of Factor 1 versus Factor 4

This factorial plan shown in Figure 6, the variable D1, "I am aware of the existence of social projects developed by HEI", the most representative in the vertical axis, it has an average response 5.43 and loading factor of 0.965697 , or is, the variable contribution value for each component.

Finally, it should also be emphasized that the internal liability of the first factors that were taken are satisfactory, and it is supported by the statistical factor analysis, which provided a loading factor value consistent with the plot of the variables in the factorial plan. For this reason, it can be said that the first factors are consistent with the variables that comprise it. 


\section{FINAL REMARKS}

The definition of social responsibility is evolving, as it covers the existing fundamental concerns in the relationship between citizens and organizations. Regarding the objectives to which the article was initially proposed, the first goal has been achieved since the professors' perceptions were raised by considering the four dimensions of CSR previously defined. According to Sánchez-Hernandez and Mainardes (2016:151) "Nowadays, Universities should not only do some add-on philantropic items, but should change their strategies and really build a responsible approach into their management activities and also into their education and research programs". In accordance with this perception, results achieved by the present study demonstrate that the economic, legal and ethical responsibilities are more positively perceived as part of the CSR than those focused on social and philanthropic initiatives. Variables such as "the existence of the code of ethics" and "investments in social projects" showed a high standard deviation, demonstrating the lack of homogeneity among the respondents.

This analysis supports that the descriptive statistics B6 variable - "The resignation and the workload reduction are harmful to the employee" with 5.67, figured as variable better perceived among professors. Equally important it highlights a variable with negative perception, A6, "Investment in physical structure is satisfactory", with 3.00 averages in the research, a characteristic that should be observed.

Multivariate step, the cluster analysis indicated the formation of three homogeneous sets. The first refers to the "code of conduct", the second covering the economic responsibilities, through the A8 variable "wage rewards are satisfactory," A7 "investment in teacher training is satisfactory," and A6 "investment in physical structure is satisfactory". Finally a large cluster composed of 24 variables and, due to the small sundry items Euclidian distances could be removed and remade test.

Factor analysis reduced the 28 variables on 4 factors, so that $72 \%$ of the original set of data is explained by the variability of these four factors. Research has shown that the main variables that make up a positive image of the socially responsible actions of the HEI are A4, "the closing of higher education is detrimental to employees of HEI" A5, "The existence of unfilled vacancies is detrimental to HEI "C5" HEI harms no one voluntarily ", and D1," I am aware of the existence of social projects developed by the HEI". These elements show, at first instance that the professors are sensitive to the economic and management problems that an HEI is subject, later on the social perception of extension actions of the HEI, community oriented projects and respect for others are essential elements for the positive image of the institution by these stakeholders. The awareness of the relevance of CSR is considered by Vázquez, Lanero and Licandro (2013) when discussing this subject under the perspective of the stakeholders, mainly employees and consumers which, in the case of the present study, is referred to the professors.

The second goal was also achieved, as summarized in Table 5. The dimensions that have more positive perceptions with regard to socially responsible actions developed by the HEI were evaluated. With regard to economic responsibility, the perception of professors is given in relation to the impact of unfilled vacancies bring to the business. The company's profitability, as signals Carroll (1991) is fundamental to the organization because of it support its other responsibilities.

As for the legal responsibility, the perception of the professors is stronger with regard to dismissal and reduction of working hours to be harmful to the employee. The access of minorities to study is the subject that deserved the highest incidence of responses of professors indicating their perception of the ethical dimension of HEI. Finally, with regard to philanthropic responsibility, professors demonstrate their perception of the development of social projects by the HEI. Promote actions that meet the demands of society is important,
BBR

14,6

605 
BBR

14,6

606

as Barbieri and Cajazeira (2012), provided that the organization is committed to its development and its results. Confirming the considerations of Grayson and Hodges (2002), social issues need to be considered by organizations to run the risk of having negative effects on the brand and lose talent. In the case of HEI, the possibility of losing professors is highly relevant for the organization. The third goal was also achieved considering that, in the analysis of data collected it was discussed the perception of professors on the socially responsible actions of the HEI.

The theoretical assumptions were confirmed by the survey: 1. It was the theoretical basis presented that in fact socially responsible actions are part of the economic, social and environmental dimensions and are studied, as there are numerous authors who address this issue. These actions contribute to the company's image, not only in the market where it sells its products and services, but internally, along with their staff, research object of this work. 2. Officials of the organizations are part of the stakeholder group, or public affected directly by corporate actions. 3 . Thus, the image that the educational institution is for professors is reflected in the relationship that they have with the students and with the image that they go to the organization. The students' decision-making to remain or not the educational institution is, therefore, the image they perceive the narrative of professors. 4. It was noted by the research that employees do not necessarily know about socially responsible activities developed by the organization they work for. This knowledge is important for forming a positive image about the organization, passing it to the students, their main consumers.

The study is limited by the sample size and size of the institution. The expansion of this study to other universities and public may bring different results. Another limitation refers to the use of the Carroll model $(1979,1991)$, due to the publication of Schwartz and Carroll, 2008, which develops the VBA model, a data collection tool that contains this new perspective, will bring new revelations about CSR. It is suggested that future studies dealing with other stakeholders of HEIs, as students, suppliers, community, regulators. Likewise, other qualitative and quantitative methods can provide a more solid overview of the study object.

Finally, this research suggests further researches and empirical results to contribute more consistently with the issue of CSR. Thus, the research aimed to contribute to empirical results, for a segment of higher education, which should also consider the applications and developments about RSC. It is recommended that HEIs invest heavily in internal communication of actions that performs the four dimensions studied in this article. Confirming Tachizawa (2004) actions socially responsible and are committed need to be strategically managed so that their results are reflected in competitive advantage. It is not enough to define and implement practices in economic, legal, ethical and philanthropic responsibilities. Reporting them to your internal audience is critical to build brand image. In practice, this is the contribution made by this article to encourage organizations to understand and monitor the awareness of its employees.

\section{REFERENCES}

Altkinson, A. A.\& Waterhouse, J. A. (1997). Stakeholders approach to strategic performance measurement. Sloan Management Review. 38 (3), p. 25-36, Spring.

Alves, E. A. (2003). Dimensões da Responsabilidade Social da empresa: uma abordagem desenvolvida a partir da visão de Bowen. Revista de Administração, 38 (1), p. 37-45, Jan.-Mar.

Alzyoud, S. A. \&Bani-Hani, K. (2015). Social responsibility in higher education institutions: application case from the Middle East. European Scientific Journal, March, 11 (8), p. 122-129.

Ansoff, I.\&MCdonnell, E. J. (1993). Implantando a administração estratégica. 2. ed. São Paulo: Atlas.

Arango, G. H. (2005). Bioestatística: teórica e computacional. Editora Koogan, Rio de Janeiro: Guanabar.

Ashley, P. A., Coutinho, R. B. G. \& Tomei, P. A. (2000). Responsabilidade Social Corporativa e Cidadania Empresarial: uma análise conceitual comparativa. Revista do TerceiroSetor - RETS, 2 (99). 
Asif, M.,Searcy, C.,Garvare, R. \& Ahmad, H. (2011). Including sustainability in business excellence models. Total quality Management and Business Excellence. 22 (7), p. 773-786.

Associação Brasileira de Normas Técnicas. (2010). ISO 26000: Diretrizes sobre responsabilidade social. Retrieved from http://www.pessoacomdeficiencia.gov.br/app/sites/default/files/arquivos/[field_generico_ imagens-filefield-description]_65.pdf.

Barbieri, J. C. \& Cajazeira, J. E. R. (2012). Responsabilidade Social Empresarial e Empresa Sustentável: da teoria à prática. 2 e. São Paulo: Saraiva.

Barnea, A.\& Rubin, A.(2010). Corporate Social Responsibility as a Conflict Between Shareholders. Journal of Business Ethics, 97, p. 71-86. Doi 10.1007/s10551-010-0496-Z.

Barnard, C. I.(1938). The Functions of the ExecutiveCambridge, MA: Harvard University Press.

Beltratti, A. (2005). The complementarity between corporategovernance and corporate social responsibility. GenevaPapers on Risk and Insurance, [S.1.], v. 30, p. 373-386.

Benabou, R. \&Tirole, J. (2010). Individual and corporatesocial responsibility. Economica 77, p. 1-19.

Bowen, H. R. (1957). Responsabilidades sociais do homem de negócios. Rio de Janeiro: Civilização brasileira.

Brasil (2013). Censo da Educação Superior 2013.Retrieved fromhttp://portal.inep.gov.br/web/censo-daeducacao-superior.

Brunk, K.H. \&Blümelhuber, C. (2011). One strike and you're out: qualitative insights into the formation of consumers' ethical company or brand perceptions. J. Bus. Res. 64 (2), p. 134-141.

Calabrese, A., Costa, R.,\&Rosati F. (2016). Gender differences in customer expectations and perceptions of corporate social responsibility. Journal of Cleaner Production, 116, p. 135-149.

Carroll, A. B. (1979). A three-dimensional conceptual model of corporate performance.Academy of Management Review, 4 (4), p. 497-505.

. (1991). The pyramid of corporate social responsibility: toward the moral management of organizational stakeholders. Business Horizons, 34 (4), p. 39-48, Jul-Aug.

Certo, S. (2003). Administração Moderna . 9. ed. São Paulo: Prentice Hall.

Cespa, G. \&Cestone, G. (2007).Corporate SocialResponsibility and Managerial Entrenchment, Journal ofEconomics and Management Strategy, [S.1.], v. 16, p. 741-771.

Cheng, B.Ioannou, I. \&Serafeim, G. (2014). Corporate Social responsibility and access to finance. Strategic management journal, 35, p. 1-23.

Clarke, T. (2005). Accounting for Enron: Shareholder valueand stakeholder interests. Corporate Governance: anInternational Review, [S.1.], v. 13, p. 598-612.

Christensen L.J., Peirce E., Hartman L.P., Hoffman W.M., \& Carrier J. (2007). Ethics, CSR, and Sustainability Education in the Financial Times Top 50 Global Business Schools:Baseline Data and Future Research Directions. Journal of Business Ethics, 73(4), p. 347-368. http://dx.doi.org/10.1007/s10551-006-9211-5

Dhaliwal D.,Li O.Z.,Tsang A.H. \& Yang Y.G. (2011). Voluntary non-financial disclosure and the cost of equity capital: the case of corporate social responsibility reporting. Accounting Review 86(1), p. 59-100.

Eccles R.,Ioannou I. \&Serafeim G. (2012). The impact of corporate sustainability on organizational processes and performance. Working paper, Harvard Business School, Harvard University, Boston, MA.

Escobar, M. A. R.,Lizote, S. A. \&Verdinelli, M. A. (2012). Relação entre orientação empreendedora, capacidade de inovação e munificência ambiental em agências de viagens. Turismo - Visão e Ação. 14 (2), p. 269-286.

European Commission (2011). A Renewed EU Strategy 2011-14 for Corporate Social Responsibility. European Commission, Brussels.

Freeman, R. E. (1984). Strategic management: a stakeholder approach. Massachusetts: Sage.

Friedman, M. (1970). The social responsibility of business is to increase its profits. The New York Times Magazine. New York, Sept.

. Milton Friedman responds. (1972). Business and Society Review, Spring, Issue 1.

Grayson, D. \&Hodges. (2002). A. Compromisso social e gestão empresarial. São Paulo: Publifolha.

Hair Jr., F., Anderson, R. E.,Tatham, R. L. \& Black, W. C. (2006). Análise multivariada de dados. Porto Alegre: Bookman.

Harjoto, M. A. \& Jo, H. (2011). Corporate Governance and CSRNexus. Journal of Business Ethics, [S.1.], v. 100, p. $45-67$

Hartley, S. (2005). Social responsibility of management.Business Date. 13 (1), March.

Instituto Ethos.(2016).Sobre o instituto. Retrievedfromhttp://www3.ethos.org.br.

Jones, T.M. (1980). Corporate social responsibility revisited redefined. California Management Review. California, XXII (2), Spring. 
Koontz, H.,Weihrich, H. \&Cannice, M. (2009). Administração: uma perspectiva empresarial. São Paulo: McGraw-Hill.

Kotler, P. \& Fox, K. (1994). Marketing estratégico para instituições educacionais. São Paulo: Atlas.

Lämsä, A.M., Vehkaperä, M., Puttonen, T. \&Pesonen, H.L.(2008). Effect of business education on women and men students' attitudes on corporate responsibility insociety. J. Bus. Ethics 82 (1), p. 45-58.

Levitt, T. (1958). The dangers of social responsibility.Harvard Business Review.Sept./Oct., p. 41-50.

Lyra, F. R \& Souza, M. J. B. (2013).Percepção das práticas de Responsabilidade Social Corporativa pelos stakeholders do Parque Beto Carrero World. Anais. XXXVII Encontro da Anpad.

Malhotra, N. (2001). Pesquisa de marketing. 3.ed. Porto Alegre: Bookman.

Martins, I.S., Fischer, F. M., Teixeira, L. R., Costa, L. A. R., Marinho, S. P., Perestrelo, J. P. P., Latorre, M. R. D. O. \& Costa, L. A. R. C. (2002). Crescimento e trabalho de estudantes de ensino fundamental e médio em São Paulo, Brasil. Rev saúde pública, 36 (1), p. 19-25.

Mattar, F.(2014). Pesquisa de Marketing, $7^{\text {a }}$ Edição. Elsevier Brasil.

Melo Neto, F.P. \& Froes, C. (1999). Gestão da responsabilidade social corporativa: o caso brasileiro. Rio de Janeiro: Qualitymark.

Merriam, S. B. (1998).Qualitative Research and Case Study Applications in Education. San Francisco: Allyn and Bacon.

Mishra, R. \&Awasthi, A. (2016). An exploratory study on awareness towards institutional social responsibility in Indian higher education institutions. Journal of Human Resource Management (19) 1, p. 56-66.

Oliveira, T. M. V. (2001).Escalas de mensuração de atitudes: Thurstone, Osgood, Stapel, Likert, Guttman, Alpert. Administração On Line, v. 2, n. 2, p. 1-25.

Othman, R.\& Othman, R. (2014). Higher education institutions and social performance: Evidence from public and private universities. International Journal of Business and Society, v. 15, n. 1, p. 1.

Porter, M. E. \& Kramer, M. R. (2002). The competitiveadvantage of corporate philanthropy. Harvard businessreview, [S.1.], p. 5-16.

Ranängen, H. (2013). Corporate Social Responsibility Practice in the Mining Industry. Doctoral thesis presented at the Lulea University of Tecnology, Department of Business Administration, Technology and Social Science. $170 \mathrm{p}$.

Rasche, A. \&Kell, G. (2010). The United Nations Global Compact:Achievements, trends and challenges. Cambridge: CambridgeUniversity Press.

Sánchez-Hernández, M. I. \&Mainardes, E. W. (2016).University social responsibility: a student base analysis in Brazil. Int Rev Public Nonprofit Mark, (13), p. 151-169. Doi 10.1007/s12208-016-0158-7.

Slavova, I. \&Bankova, Y. (2015). Corporate social responsibility in business and management university education: the relevancy to the business practices in Bulgaria. European Journal of Business and Economics, 10 (2), p. 57-64.

Stoner, J. A. F. \& Freeman, R. E.(1999).Administração.Rio de Janeiro: LTC.

Sautter, E.T. \&Leisen, B. (1999). Managing stakeholders: a tourism planning model. Annals of tourism research. 26 (2).

Schwartz, M. S. \& Carroll, A. B. (2008).Stakeholder Integrating and Unifying Competing and Complementary Frameworks: The Search for a Common Core in the Business and Society Field. Business \&Society, June; 47 (2), p. 148-186.

Sender, G., \&Fleck, D. L. (2004) Folga organizacional e gestão de stakeholders: um estudo em bancos brasileiros. In: Encontro Nacional dos Programasde Pós-Graduaçãoem Administração. Anais ANPAD.

Spence, M. (1973). Job market signaling. Quarterly Journal of Economics 87(3), p.355-374.

Stadler, A. (2007). Responsabilidade social e imagem corporativa de uma instituição de ensino superior na percepção do corpo docente. Dissertação de Mestrado. UNIVALI - Universidade do Vale do Itajaí, Biguaçu - SC.

Tachizawa, T. (2004). Gestão ambiental e responsabilidade social corporativa: estratégias de negócios focadas na realidade brasileira. 2 ed. São Paulo: Atlas.

Vázquez, J. L., Lanero, A., Licandro, O. (2013). Corporate social responsibility and Higher Education: Uruguay University students' perceptions. Economic\&Sociology (6), 2, p. 145-157, doi: 10.14254/2071789X/6-2/13.

Verdinelli, M. A., Souza, M. J. B. \& Ferras, J.J. (2007). Percepção da imagem e satisfação em egressos universitários: uma análise correlacional. Anais: VII Coloqui Internacional sobre Gestion Universitaria en America del Sur. Movilidad, Gobernabilidad e Integración Regional. Mar del Plata, Argentina. 29 nov a 1 Dec.

Yin, R. K. (2001).Estudo de caso: planejamento e métodos. Porto Alegre: Bookman. 